\title{
Epidemiological and clinical characteristics of patients with COVID-19 in Islamic Republic of Iran
}

Marzieh Araban, ${ }^{1}$ Mahmood Karimy, ${ }^{2}$ Hamid Koohestani, ${ }^{2}$ Ali Montazeri ${ }^{3}$ and Daniel Delaney ${ }^{4}$

${ }^{1}$ Department of Health Education and Promotion, Social Determinants of Health Research Center, Public Health School, Ahvaz Jundishapur University of Medical Sciences, Ahvaz, Islamic Republic of Iran. ${ }^{2}$ Social Determinants of Health Research Center, Saveh University of Medical Sciences, Saveh, Islamic Republic of Iran. ${ }^{3}$ Mental Health Research Group, Mother and Child Health Research Centre, Iranian Institute for Health Sciences Research, ACECR, Tehran, Islamic Republic of Iran. ${ }^{4}$ Department of Psychology, University of Rhode Island, Kingston, Rhode Island, United States of America. (Correspondence to: Mahmood Karimy: karimymahmood@yahoo.com).

\begin{abstract}
Background: Coronavirus disease 2019 (COVID-19) is a worldwide public health emergency.

Aims: This study aimed to investigate the epidemiological and clinical characteristics of patients with COVID-19 in Saveh city, Islamic Republic of Iran in 2020.
\end{abstract}

Methods: In this descriptive analytical research, 3181 patients suspected of having COVID-19 who visited Saveh medical centres were investigated. Patients were confirmed with COVID-19 using polymerase chain reaction testing. Data on sociodemographic, epidemiological and clinical characteristics of the patients were collected using a validated form through interviews and medical records. The chi-squared, $t$ and Fisher exact tests were used to assess differences in sociodemographic, epidemiological and clinical characteristics between patients with positive and negative polymerase chain reaction results. Logistic regression analysis was used to examine the association between independent variables and death from COVID-19.

Results: About half the patients (48.3\%) had a history of chronic disease. Diabetes (16.2\%), high blood pressure (14.8\%) and cardiovascular disease (12.4\%) were the most prevalent chronic diseases among patients who were confirmed positive for COVID-19. Risk factors for death among confirmed COVID-19 patients were: intubation (odds ratio (OR) $=8.97$; 95\% confidence interval (CI): 5.15-15.63), age $\geq 80$ years (OR = 5.81; 95\% CI: 1.91-17.60), oxygen saturation < 93\% $(\mathrm{OR}=2.48 ; 95 \% \mathrm{CI}$ : 1.51-4.08), diabetes ( $\mathrm{OR}=1.88$; 95\% CI: 1.00-3.54) and shortness of breath (OR = 1.70; 95\% CI: 1.02-2.82).

Conclusion: Given the greater risks of contracting and dying from COVID-19 in certain groups of patients, health education programmes targeting these groups are recommended.

Keywords: coronavirus, COVID-19, risk factors, public health, Iran

Citation: Araban M; Karimy M; Koohestani H; Montazeri A; Delaney D. Epidemiological and clinical characteristics of hospitalized patients with COVID-19 in Islamic Republic of Iran. East Mediterr Health J. 2022;28(4):249-257. https://doi.org/10.26719/emhj.22.008

Received: 21/12/20; accepted: 06/10/21

Copyright @ World Health Organization (WHO) 2022. Open Access. Some rights reserved. This work is available under the CC BY-NC-SA 3.o IGO license (https://creativecommons.org/licenses/by-nc-sa/3.o/igo)

\section{Introduction}

Chinese scientists isolated a new coronavirus from patients in Wuhan, China on 7 January 72020 (1). The cause of the disease named coronavirus disease 2019 (COVID-19) was a new virus strain called severe acute respiratory coronavirus 2 (SARS-CoV-2) (2). The World Health Organization (WHO) declared the outbreak a public health emergency of international concern on 30 January 2020 (3). The pandemic has affected high- and low-income countries and millions of people have been infected by SARS-CoV-2 (4-6). In March 2020, WHO declared COVID-19 a pandemic (global epidemic) (7). The high rate of virus spread have led to high rates of infection and mortality (8). Given the severity of the pandemic and lack of effective treatments, efforts were made to slow the spread of the disease to allow time to produce and administer effective vaccines and/or treatment $(8,9)$.

Until 2 decades ago, human coronaviruses were only known to cause uncomplicated respiratory infections such as the common cold. However, two new coronaviruses, severe acute respiratory syndrome (SARS) and Middle East respiratory syndrome (MERS), caused severe outbreaks around the world in 2003 and 2012, respectively (10). Infection with SARS-Cov-2 is very similar to other viral infections in terms of clinical manifestations (7,11), and patients show a wide range of clinical symptoms from mild and asymptomatic to very severe including viral pneumonia, respiratory failure and even death (12). The main symptoms of COVID-19 include fever, cough, and fatigue. Other symptoms include headache, haemoptysis (bloody sputum), diarrhoea, shortness of breath and lymphopenia $(12,13)$. Severe cases have also been associated with heart damage and pulmonary opacification. A high percentage of people (about $80 \%$ ) show asymptomatic infection or mild symptoms of a cold, while about $20 \%$ experience more severe symptoms of the disease, such as, pneumonia, sepsis, septic shock and acute respiratory distress syndrome (14-16). Depending on the severity of the disease, patients may need to be assisted in breathing (e.g. 
intubation). The mortality rate of COVID-19 is about $2 \%$, although this rate varies slightly across studies $(6,17)$.

Some research has examined what clinical and epidemiological factors predict mortality and case severity from COVID-19. Given the variability in severity of the disease, it is important to identify which factors may be associated with higher rates of mortality and severe disease $(12,18)$. Greater severity of COVID-19 has been found to be associated with higher levels of D-dimer, procalcitonin and C-reactive protein at hospital admission, as well as older age (14). Risk factors for death from COVID-19 include older age, cardiac disease, hypertension, diabetes mellitus, cancer, chronic obstructive pulmonary disease, higher levels of D-dimer and C-reactive protein at admission, lymphopenia, oxygen saturation levels $\left(\mathrm{PO}_{2)}\right.$ during the course of the clinical visit, $\mathrm{CD} 3+$ and $\mathrm{CD} 8+\mathrm{T}$ cells $\leq 75$ cells $/ \mu \mathrm{L}$, cardiac troponin $\mathrm{I} \geq 0.05 \mathrm{ng} / \mathrm{mL}$, and higher body temperature (14-19).

Given that COVID-19 is a new disease, knowledge about the epidemiological and clinical characteristics of those infected with COVID-19 is still limited. Further studies are needed to identify factors associated with disease severity and death in order to properly manage this epidemic and take effective preventive and treatment measures. Therefore, the aim of this study was to identify the risk factors for COVID-19 disease severity and death in a community sample in Saveh, Islamic Republic of Iran.

\section{Methods}

\section{Study design and sample}

We conducted a descriptive analytical study of patients suspected of having SARS-Cov-2 infection who visited Saveh medical centres from 9 February to 25 October 2020. Patients were included in the study if they were suspected of SARS-Cov-2 infection and agreed to participate in the study. If patients refused to consent and/or their medical record was not available, they were excluded.

\section{Data collection}

Data were collected by interviews and accessing information in patients' medical records. For hospitalized patients, the research team conducted interviews at medical centres after obtaining the necessary permission from the hospital administrators. Participants at outpatient centres and patients discharged from the hospital were contacted to obtain necessary data. After explaining the research objectives and obtaining the patient's consent, the researchers interviewed the patients and collected data while maintaining confidentiality. Data from patients' files were also accessed with permission from hospital authorities and patients.

\section{Questionnaire}

A questionnaire developed by the research team was used to collect data. The questionnaire was created by reviewing scientific literature and consulting with experts in infectious diseases and epidemiology. The form consisted of sociodemographic information (such as age, occupation, sex, occupation, level of education and place of residence) and epidemiological and clinical characteristics of those with COVID-19. Epidemiological information collected included: history of possible contact with COVID-19 patients; history of underlying diseases (cancer, hypertension, diabetes mellitus, cardiovascular disease, chronic obstructive pulmonary disease, asthma, renal disease, liver disease and haematological disease), smoking status and history of substance abuse. Clinical information collected included: duration of hospitalization; shortness of breath (dyspnoea), $\mathrm{PO}$ 2, cough, fever, intubation, radiological evidence showing lesions compatible with COVID-19 in computed tomography scan as confirmed by a radiologist, loss of consciousness, gastrointestinal disorders, nausea, vomiting, diarrhoea, and myalgia or fatigue.

The content validity of the questionnaire was determined by both qualitative and quantitative methods. The questionnaire was given to 12 professors in the fields of infectious diseases, internal medicine and epidemiology, and they were asked to examine and give feedback on the terminology, order of items and grammar in the form (e.g. items to add or discard). In addition, the content validity ratio and content validity index were calculated to examine the content validity. To determine the content validity ratio, the experts were asked about the need for or not of each item on the form; items with values $>0.56$ were retained on the questionnaire. To determine the content validity index, the relevance, clarity and simplicity of each item were reviewed and items with values $>0.79$ were retained.

\section{Case definitions}

A definitive COVID-19 case was determined by a positive polymerase chain reaction (PCR) test. A suspected case was a patient with at least one of the following symptoms, which could not be attributed to another etiological agent: dry cough, chills, sore throat, shortness of breath and fever. A negative case of the disease was determined as a negative PCR result.

\section{Data analysis}

Data were analysed using SPSS, version 21. The chisquared, independent sample $t$ and Fisher exact tests were used to compare patients by PCR status and demographic characteristics. In addition, a logistic regression analysis was performed to determine the association between independent variables and death from COVID-19. Only those independent variables that showed significant associations with death $(P \leq 0.05)$ in the univariable analysis were included in the multivariable logistic regression models.

\section{Ethical concerns}

Permission to conduct the research was obtained from the Saveh Medical Centres. This research was approved 
by the Ethics Committee of Saveh University of Medical Sciences (IR.SAVEHUMS.REC.1399.002).

\section{Results}

A total of 3181 patients were included in the study. Their mean age (standard deviation (SD)) was 52.6 (20.8) years. Based on the laboratory data (PCR result), 1422 (44.7\%) patients were positive for COVID-19 and 1759 (55.3\%) were negative. Of the 3181 patients, 310 (9.7\%) died; of these patients, 192 (61.9\%) were PCR-positive for COVID-19, while 118 (38.1\%) were PCR-negative.

\section{Patients who survived}

Of the 2871 patients who survived, 1230 (42.8\%) were PCR-positive for COVID-19. The mean (SD) age of these COVID-19-positive patients was 53.7 (18.9) years. The mean (SD) duration of hospitalization was 6.5 (8.5) days. Of the COVID-19-positive patients, 584 (47.5\%) were men and $943(76.7 \%)$ reported a history of contact with COV-
ID-19 patients. Half (50.3\%) of all the patients who survived (either positive or negative) reported a history of contact with COVID-19 patients. There were significant differences between the PCR-positive and PCR-negative patients in age, smoking, substance addiction, history of contact with COVID-19 patients and duration of hospitalization $(P<0.05)$. The findings are presented in Table 1.

About half of all the patients (48.3\%) had a history of chronic disease. The most prevalent chronic diseases among patients who survived and were PCR-positive for COVID-19 included diabetes (16.3\%), high blood pressure (14.9\%) and cardiovascular diseases (12.4\%). Significantly more patients who were PCR-positive had diabetes than PCR-negative patients (Table 2).

The symptoms reported or experienced by PCRpositive patients at hospital admission were: shortness of breath (42.0\%), $\mathrm{PO}_{2}<93 \%(39.7 \%)$, cough $(37.2 \%)$ and fever (36.8\%). A significantly greater proportion of PCRpositive patients $(39.7 \%)$ had a $\mathrm{PO}_{2}$ saturation $<93 \%$ than

\begin{tabular}{|c|c|c|c|c|c|c|}
\hline \multirow[t]{2}{*}{ Variable } & \multicolumn{2}{|c|}{ Died $(n=310)$} & \multirow[t]{2}{*}{$\mathbf{P}$} & \multicolumn{2}{|c|}{ Survived $(n=2871)$} & \multirow[t]{2}{*}{$\mathbf{P}$} \\
\hline & $\begin{array}{c}\text { Positive PCR } \\
(n=192)\end{array}$ & $\begin{array}{l}\text { Negative PCR } \\
\quad(n=118)\end{array}$ & & $\begin{array}{c}\text { Positive PCR } \\
(n=1230)\end{array}$ & $\begin{array}{l}\text { Negative PCR } \\
\quad(n=1641)\end{array}$ & \\
\hline Age in years, no. (\%) & & & $0.02^{\mathrm{a}}$ & & & $0.001^{\mathrm{a}}$ \\
\hline $0-15$ & 0 & 0 & & $16(1.3)$ & $61(3.7)$ & \\
\hline $16-20$ & $1(0.5)$ & $1(0.8)$ & & $50(4.1)$ & $88(5.4)$ & \\
\hline $21-30$ & $3(1.6)$ & $5(4.2)$ & & $154(12.5)$ & $290(17.6)$ & \\
\hline $31-40$ & $8(4.2)$ & $12(10.2)$ & & $227(18.5)$ & $287(17.5)$ & \\
\hline $41-50$ & $23(12)$ & $6(5.0)$ & & $228(18.5)$ & $213(13.0)$ & \\
\hline $51-60$ & $29(15.1)$ & $13(11.0)$ & & $201(16.3)$ & $200(12.2)$ & \\
\hline $61-70$ & $38(19.8)$ & $29(24.6)$ & & $165(13.4)$ & $199(12.1)$ & \\
\hline $71-80$ & $60(31.3)$ & $31(26.3)$ & & $133(10.8)$ & $183(11.1)$ & \\
\hline$\geq 80$ & $29(15.1)$ & $20(16.9)$ & & $56(4.6)$ & $118(7.2)$ & \\
\hline Age in years, mean (SD) & $71.7(15.0)$ & $69.3(17.8)$ & 0.05 & $53.7(18.9)$ & $51.5(22.2)$ & $0.01^{b}$ \\
\hline Sex, no. (\%) & & & $0.003^{\mathrm{a}}$ & & & $0.35^{\mathrm{a}}$ \\
\hline Male & $112(58.3)$ & $48(40.7)$ & & $584(47.5)$ & $758(46.2)$ & \\
\hline Female & $80(41.7)$ & $70(59.3)$ & & $646(52.5)$ & $883(53.8)$ & \\
\hline $\begin{array}{l}\text { Contact with COVID-19 } \\
\text { patient, no. (\%) }\end{array}$ & & & $0.002^{\mathrm{a}}$ & & & $0.001^{\mathrm{a}}$ \\
\hline Yes & $50(26.0)$ & $14(11.9)$ & & $943(76.7)$ & $500(30.5)$ & \\
\hline No & $142(74.0)$ & $104(88.1)$ & & $287(23.3)$ & $1141(69.5)$ & \\
\hline Smoking, no. (\%) & & & $0.432^{c}$ & & & $0.003^{\mathrm{a}}$ \\
\hline Yes & $1(0.5)$ & $1(0.8)$ & & $8(0.7)$ & $34(2.1)$ & \\
\hline No & $191(99.5)$ & $117(99.2)$ & & $1222(99.3)$ & 1607 (97.9) & \\
\hline Addiction, no. (\%) & & & $0.145^{c}$ & & & $0.001^{\mathrm{a}}$ \\
\hline Yes & $2(1.0)$ & $4(3.4)$ & & $5(0.4)$ & $37(2.3)$ & \\
\hline No & 190 (99.0) & $114(96.6)$ & & $1225(99.6)$ & $1604(97.7)$ & \\
\hline $\begin{array}{l}\text { Days in hospital, mean } \\
\text { (SD) }\end{array}$ & $7.2(5.7)$ & $9.8(15.4)$ & $0.215^{\mathrm{b}}$ & $6.5(8.5)$ & $3.5(8.1)$ & $0.001^{b}$ \\
\hline
\end{tabular}

$P C R=$ polymerase chain reaction test $S D=$ standard deviation.

${ }^{a}$ Chi-squared test.

${ }^{b}$ Student t-test.

'Fisher exact test. 


\begin{tabular}{|c|c|c|c|c|c|c|}
\hline \multirow[t]{3}{*}{ Underlying condition } & \multicolumn{2}{|c|}{ Died } & \multirow[t]{2}{*}{$\boldsymbol{P}$} & \multicolumn{2}{|c|}{ Survived } & \multirow[t]{3}{*}{$\boldsymbol{P}$} \\
\hline & $\begin{array}{c}\text { Positive PCR } \\
\quad(n=192)\end{array}$ & $\begin{array}{c}\text { Negative PCR } \\
\quad(n=118)\end{array}$ & & $\begin{array}{c}\text { Positive PCR } \\
(n=1230)\end{array}$ & $\begin{array}{c}\text { Negative PCR } \\
\quad(n=1641)\end{array}$ & \\
\hline & No. (\%) & No. (\%) & & No. (\%) & No. (\%) & \\
\hline Cancer & & & $0.252^{\mathrm{a}}$ & & & $0.752^{\mathrm{a}}$ \\
\hline Yes & $5(2.6)$ & $6(5.1)$ & & $12(1.0)$ & $18(1.1)$ & \\
\hline No & $187(97.4)$ & $112(94.9)$ & & 1218 (99) & 1623 (98.9) & \\
\hline Hypertension & & & $0.694^{\mathrm{a}}$ & & & $0.609^{a}$ \\
\hline Yes & $41(21.4)$ & $23(19.5)$ & & $183(14.9)$ & $233(14.2)$ & \\
\hline No & $151(78.6)$ & $95(80.5)$ & & $1047(85.1)$ & $1408(85.8)$ & \\
\hline Diabetes & & & $0.803^{\mathrm{a}}$ & & & $0.005^{a}$ \\
\hline Yes & $48(25.0)$ & $31(26.3)$ & & $200(16.3)$ & $206(12.6)$ & \\
\hline No & $144(75.0)$ & $87(73.7)$ & & $1030(83.7)$ & $1435(87.4)$ & \\
\hline Cardiovascular diseases & & & $0.594^{\mathrm{a}}$ & & & $0.083^{a}$ \\
\hline Yes & $44(22.9)$ & $24(20.3)$ & & $153(12.4)$ & $241(14.7)$ & \\
\hline No & $148(77.1)$ & $94(79.7)$ & & $1077(87.6)$ & $1400(85.3)$ & \\
\hline COPD & & & $0.072^{\mathrm{a}}$ & & & $0.382^{\mathrm{a}}$ \\
\hline Yes & $6(3.1)$ & $9(7.6)$ & & $18(1.5)$ & $18(1.1)$ & \\
\hline No & $186(96.9)$ & $109(92.4)$ & & $1212(98.5)$ & $1623(98.9)$ & \\
\hline Asthma & & & $0.03^{c}$ & & & $0.025^{a}$ \\
\hline Yes & $3(1.6)$ & $7(5.9)$ & & $26(2.1)$ & $58(3.5)$ & \\
\hline No & 189 (98.4) & 111 (94.1) & & 1204 (97.9) & $1583(96.5)$ & \\
\hline Renal disease & & & $0.605^{a}$ & & & $0.787^{\mathrm{a}}$ \\
\hline Yes & $8(4.2)$ & $5(4.2)$ & & $23(1.9)$ & $33(2.0)$ & \\
\hline No & $184(95.8)$ & $113(95.8)$ & & 1207 (98.1) & 1608 (98.o) & \\
\hline Liver disease & & & $0.865^{c}$ & & & $0.538^{c}$ \\
\hline Yes & $2(1.1)$ & $1(0.8)$ & & $2(0.2)$ & $7(0.4)$ & \\
\hline No & 190 (98.9) & 117 (99.2) & & $1228(99.8)$ & $1634(99.6)$ & \\
\hline Blood disease & & & $0.928^{c}$ & & & $0.569^{a}$ \\
\hline Yes & $3(1.6)$ & $2(1.7)$ & & $6(0.5)$ & $17(1.0)$ & \\
\hline No & $189(98.4)$ & 116 (98.3) & & 1224 (99.5) & 1624 (99.0) & \\
\hline
\end{tabular}

PCR= polymerase chain reaction test; $C O P D=$ chronic obstructive pulmonary disease.

${ }^{a}$ Chi-squared test.

${ }^{b}$ Student t-test.

Fisher exact test.

PCR-negative patients (31.2\%; $P=0.001)$. In addition, a significantly greater proportion of PCR-positive than PCR-negative patients experienced fever, cough, fatigue, shortness of breath, loss of taste and loss of smell ( $P$ $<0.05)$. No significant differences were found between PCR-positive and PCR-negative patients in rate of intubation ( $1.5 \%$ versus $2.0 \%$, respectively; $P=0.27$ ) and manifestations observed on computed tomography scans (34.8\% versus $27.7 \% ; P=0.52$ ). Full results are reported in Table 3.

\section{Patients who died}

Of the 310 patients who died, 192 (61.9\%) were PCR-positive for COVID-19. The mean (SD) age of these patients was 70.0 (16.1) years and the mean (SD) duration of hospitalization was 7.2 (SD 5.7) days. Of all patients who died, those aged 71-80 years had the highest rate of death (29.4\%) (Table 1). Of the patients who died and were PCR-positive for COVID-19, more than half (58.3\%) were men. As regards underlying conditions, $69.6 \%$ of all the patients who died had a history of chronic disease: diabetes, cardiovascular disease and hypertension were the most common diseases, found in $25.5 \%, 21.9 \%$ and $20.6 \%$, respectively (Table 2).

Among those who died, a significantly greater proportion of patients who were PCR-positive for COVID-19 than PCR-negative patients had the following clinical signs: fever, cough and myalgia or fatigue $(P<0.05)$. However, a significantly greater proportion of patients who were PCR-negative than PCR-positive experienced loss of consciousness $(P=0.001)$ (Table 3 ).

In multivariable logistic regression models the following factors were significantly associated with 


\begin{tabular}{|c|c|c|c|c|c|c|}
\hline \multirow[t]{4}{*}{ Variable } & \multicolumn{2}{|c|}{ Died } & \multirow[t]{2}{*}{$\mathbf{P}$} & \multicolumn{2}{|c|}{ Survived } & \multirow[t]{3}{*}{$\mathbf{P}^{\mathbf{a}}$} \\
\hline & $\begin{array}{c}\text { Positive PCR } \\
\quad(n=192)\end{array}$ & $\begin{array}{c}\text { Negative PCR } \\
\quad(n=118)\end{array}$ & & $\begin{array}{l}\text { Positive PCR } \\
(\mathbf{n}=1230)\end{array}$ & $\begin{array}{l}\text { Negative PCR } \\
\quad(n=1641)\end{array}$ & \\
\hline & No. (\%) & No. (\%) & & No. (\%) & No. (\%) & \\
\hline & $192(61.9)$ & $118(38.1)$ & & $1230(42.8)$ & $1641(57.2)$ & \\
\hline \multicolumn{7}{|c|}{ CT scan manifestation } \\
\hline Yes & $72(37.5)$ & $43(36.4)$ & $0.346^{a}$ & $429(34.9)$ & $454(27.7)$ & 0.521 \\
\hline No & $2(1.0)$ & $4(3.4$ & & $22(1.8)$ & $49(3.0)$ & \\
\hline No CT scan & $118(61.5)$ & $71(60.2)$ & & $779(63.3)$ & $1138(69.3)$ & \\
\hline \multicolumn{7}{|c|}{ Loss of consciousness } \\
\hline Yes & $15(7.8)$ & $27(22.9)$ & $0.001^{a}$ & $9(0.8)$ & $54(3.3)$ & 0.001 \\
\hline No & $177(92.2)$ & $91(77.1)$ & & $1221(99.2)$ & $1587(96.7)$ & \\
\hline \multicolumn{7}{|l|}{ Intubation } \\
\hline Yes & $86(44.8)$ & $58(49.2)$ & $0.455^{\mathrm{a}}$ & $18(1.5)$ & $33(2.0)$ & 0.272 \\
\hline No & $106(55.2)$ & $60(50.8)$ & & $1212(98.5)$ & $1608(98.0)$ & \\
\hline \multicolumn{7}{|l|}{$\mathrm{PO}_{2} \%$} \\
\hline$\geq 93$ & $55(28.6)$ & $27(22.9)$ & $0.264^{a}$ & $742(60.3)$ & $1129(68.8)$ & 0.001 \\
\hline$<93$ & $137(71.4)$ & $91(77.1)$ & & $488(39.7)$ & $512(31.2)$ & \\
\hline \multicolumn{7}{|l|}{ Fever } \\
\hline Yes & $60(31.2)$ & $25(21.2)$ & $0.05^{\mathrm{a}}$ & $453(36.8)$ & $413(25.2)$ & 0.001 \\
\hline No & $132(68.8)$ & $93(78.8)$ & & $777(63.2)$ & $1228(74.8)$ & \\
\hline \multicolumn{7}{|l|}{ Cough } \\
\hline Yes & $53(27.6)$ & $16(13.6)$ & $0.004^{a}$ & $458(37.2)$ & $408(24.9)$ & 0.001 \\
\hline No & $139(72.4)$ & $102(86.4)$ & & $772(62.8)$ & $1233(75.1)$ & \\
\hline \multicolumn{7}{|c|}{ Myalgia or fatigue } \\
\hline Yes & $26(13.5)$ & $5(4.2)$ & $0.008^{\mathrm{a}}$ & $304(24.7)$ & $215(13.1)$ & 0.001 \\
\hline No & $166(86.5)$ & $113(95.8)$ & & $926(75.3)$ & $1426(86.9)$ & \\
\hline \multicolumn{7}{|c|}{ Shortness of breath } \\
\hline Yes & $101(52.6)$ & $63(53.4)$ & $0.893^{\mathrm{a}}$ & $518(42.1)$ & $484(29.5)$ & 0.001 \\
\hline No & $91(47.4)$ & $55(46.6)$ & & $712(57.9)$ & $1157(70.5)$ & \\
\hline \multicolumn{7}{|c|}{ Gastrointestinal disorders } \\
\hline Yes & $5(2.6)$ & $3(2.5)$ & $0.146^{c}$ & $55(4.5)$ & $75(4.7)$ & 0.643 \\
\hline No & $187(97.4)$ & $115(97.5)$ & & $1175(95.5)$ & $1566(95.3)$ & \\
\hline \multicolumn{7}{|l|}{ Nausea } \\
\hline Yes & $3(1.6)$ & $5(4.2)$ & $0.149^{c}$ & $73(5.9)$ & $76(4.6)$ & 0.119 \\
\hline No & $189(98.4)$ & $113(95.8)$ & & $1157(94.1)$ & $1565(95.4)$ & \\
\hline \multicolumn{7}{|l|}{ Vomiting } \\
\hline Yes & $3(1.6)$ & $4(3.4)$ & $0.293^{c}$ & $52(4.2)$ & $73(4.4)$ & 0.774 \\
\hline No & $189(98.4)$ & $114(96.6)$ & & $1178(95.8)$ & $1568(95.6)$ & \\
\hline \multicolumn{7}{|l|}{ Diarrhoea } \\
\hline Yes & $1(0.5)$ & $2(1.7)$ & $0.305^{c}$ & $53(4 \cdot 3)$ & $58(3.5)$ & 0.287 \\
\hline No & 191 (99.5) & $116(98.3)$ & & 1177 (95.7) & $1583(96.5)$ & \\
\hline \multicolumn{7}{|l|}{ Loss of taste } \\
\hline Yes & $9(4.7)$ & $2(1.7)$ & $0.167^{c}$ & $31(2.5)$ & $22(1.3)$ & 0.020 \\
\hline No & $183(95.3)$ & 116 (98.3) & & 1199 (97.5) & $1619(98.7)$ & \\
\hline \multicolumn{7}{|l|}{ Loss of smell } \\
\hline Yes & $11(5.7)$ & $3(2.5)$ & $0.190^{c}$ & $22(1.8)$ & $14(0.9)$ & 0.028 \\
\hline No & $181(94.3)$ & 115 (97.5) & & $1208(98.2)$ & 1627 (99.1) & \\
\hline
\end{tabular}

$\mathrm{PCR}=$ polymerase chain reaction; $\mathrm{CT}=$ computed tomography; $\mathrm{PO} 2=$ oxygen partial pressure.

${ }^{a}$ Chi-squared test.

${ }^{b}$ Student t-test.

'Fisher exact test. 


\begin{tabular}{|c|c|c|c|c|c|}
\hline Variable & B & SE & Wald & $\mathbf{P}$ & OR $(95 \% \mathrm{CI})$ \\
\hline Loss of consciousness & 0.97 & 0.62 & 2.45 & 0.11 & $2.65(0.78-9.00)$ \\
\hline Intubation & 2.19 & 0.28 & 60.12 & 0.001 & $8.97(5.15-15.63)$ \\
\hline \multicolumn{6}{|l|}{$\mathrm{PO}_{2}, \%$} \\
\hline \multicolumn{6}{|l|}{$\geq 93$ (ref.) } \\
\hline$<93$ & 0.91 & 0.25 & 12.96 & 0.001 & $2.48(1.51-4.08)$ \\
\hline Cough & 0.46 & 0.27 & 2.88 & 0.08 & $1.58(0.93-2.69)$ \\
\hline Myalgia and fatigue & 0.39 & 0.36 & 1.18 & 0.27 & $1.48(0.72-3.04)$ \\
\hline Shortness of breath & 0.53 & 0.25 & 4.20 & 0.04 & $1.70(1.02-2.82)$ \\
\hline Hypertension & 0.66 & 0.65 & 1.04 & 0.30 & $1.94(0.54-6.99)$ \\
\hline Diabetes & 0.63 & 0.32 & 3.83 & 0.05 & $1.88(1.00-3.54)$ \\
\hline \multicolumn{6}{|l|}{ Age in years } \\
\hline \multicolumn{6}{|l|}{$<80$ (ref.) } \\
\hline$\geq 80$ & 1.76 & 0.56 & 9.60 & 0.002 & $5.81(1.91-17.62)$ \\
\hline
\end{tabular}

COVID-19= coronavirus disease 2019; $\mathrm{SE}=$ standard error; $\mathrm{OR}=$ odds ratio; $\mathrm{CI}=$ confidence intervals; $\mathrm{PO}=$ oxygen partial pressure; ref.: reference category.

death in PCR-positive patients: intubation, $\mathrm{PO} 2<93 \%$, shortness of breath, diabetes and age $\geq 80$ years (Table 4 ).

\section{Discussion}

This study assessed the epidemiological and clinical characteristics of people infected with COVID-19 in Saveh, Islamic republic of Iran. The mean age of PCR-positive COVID-19 patients was 53.7 years which was significantly older than that of PCR-negative patients. This finding is consistent with previous studies that indicated age is a risk factor for infection with COVID-19 (19-21). A study in China reported that the mean age of patients with COVID-19 was 59 years (22).

In our study, just over half of the patients (52.8\%) were women. A possible explanation for this finding might the fact that, in Iranian culture, women tend to be tasked with shopping for daily necessities. Therefore, women may be at higher risk of being exposed to COVID-19 in crowded spaces such as malls and bakeries. Although most of the patients in this study were women, the death rate was higher in men. Some biological differences between men and women might explain the difference, as described by an earlier report (23).

In our study, $13.5 \%$ of the COVID-19 positive patients died. This was more than what reported in other studies $(24,25)$, which ranged between $3.0 \%$ and $11.0 \%$. However, our rate was similar to the rate reported in another study (20). It has been documented that the mortality rates of COVID-19 are under-reported (19). Several factors contribute to the mortality rate, including quality and quantity of health care services, prevalence of chronic disease and epidemic phase $(26,27)$. Our findings show that deaths were highest in elderly patients and patients with chronic diseases (e.g. high blood pressure, diabetes and cardiovascular disease). These findings highlight the importance of identifying susceptible groups, such as patients with a history of chronic diseases, and establishing a tailored prevention approach for these high-risk groups. Recently, research indicates that the rate of recovery from COVID-19 is increasing $(28,29)$, which may be due to increased knowledge about COVID-19.

Most of PCR-positive patients reported a history of contact with others who were positive for COVID-19. This finding may indicate non-adherence to preventive behaviours and future studies should explore ways to increase preventative behaviours to reduce COVID-19 transmission; for instance, public health education at the population level that encourages the adoption of preventive strategies (17) such as wearing face masks, physical distancing and washing hands. In addition, launching public health campaigns should be a top priority for government officials. Furthermore, proven strategies of isolating infected people and effective contact tracing is necessary to control the COVID-19 pandemic (30).

Tobacco smoking and addiction were not associated with death in patients with PCR-confirmed COVID-19. Among patients who were PCR-negative for COVID-19, the rate of addiction was slightly higher than that of PCR-positive patients. Because of the small number of patients who reported addiction and tobacco smoking, this finding should be investigated in future studies. Absolute and relative frequency of epidemiological and clinical factors of patients have been investigated in this study. Our results are consistent with earlier studies $(7,18,20)$ showing that COVID-19 is a respiratory disease with symptoms such as myalgia, cough and respiratory issues, gastrointestinal problems, and loss of taste and smell.

Due to the nature of the study design, much of the data were self-reported (e.g. contact with a COVID-19 patient, smoking and addiction) and therefore may be subject to recall bias, and also respondent bias and social desirability bias, which is a limitation of our study. For instance, future studies may want to assess past or 
current addiction more thoroughly or with a validated measure.

Implementing public health education programmes and campaigns to increase adoption of preventive behaviours to reduce transmission of COVID-19, especially in individuals with comorbidities and clinical features associated with higher risk, is highly recommended.

Funding: None.

Competing interests: None declared.

\section{Caractéristiques épidémiologiques et cliniques des patients atteints de COVID-19 en République islamique d'Iran \\ Résumé}

Contexte : La maladie à coronavirus 2019 (COVID-19) constitue une urgence de santé publique mondiale.

Objectifs : La présente étude visait à étudier les caractéristiques épidémiologiques et cliniques des patients atteints de COVID-19 dans la ville de Saveh (République islamique d'Iran) en 2020.

Méthodes: Dans cette recherche analytique descriptive, 3181 patients suspectés d'être atteints de COVID-19 et ayant consulté dans les centres médicaux de Saveh ont été examinés. Les cas de COVID-19 ont été confirmés par la méthode de réaction en chaîne par polymérase (PCR). Les données sur les caractéristiques sociodémographiques, épidémiologiques et cliniques des patients ont été recueillies à l'aide d'un formulaire validé par le biais d'entretiens et de dossiers médicaux. Le test du $\chi^{2}$, le test de $t$ et le test exact de Fisher ont été utilisés pour évaluer les différences de caractéristiques sociodémographiques, épidémiologiques et cliniques entre les patients ayant des résultats positifs et négatifs à la PCR. L'analyse de régression logistique a été utilisée pour examiner l'association entre les variables indépendantes et les décès dus à la COVID-19.

Résultats : Environ la moitié des patients $(48,3 \%)$ avaient des antécédents de maladie chronique. Le diabète (16,2 \%), l'hypertension artérielle (14,8 \%) et les maladies cardiovasculaires (12,4\%) étaient les maladies chroniques les plus courantes chez les patients ayant obtenu un résultat positif au test COVID-19. Les facteurs de risque de décès chez les patients atteints de COVID-19 étaient les suivants : intubation (odds ratio (OR) $=8,97$; intervalle de confiance (IC) à $95 \%: 5,15-15,63)$, âge supérieur ou égal à 80 ans (OR $=5,81$; IC à $95 \%: 1,91-17,60)$, saturation en oxygène inférieure à $93 \%(\mathrm{OR}=2,48$; IC à $95 \%: 1,51-4,08)$, diabète $(\mathrm{OR}=1,88$; IC à $95 \%: 1,00-3,54)$ et dyspnée $(\mathrm{OR}=1,70 ; \mathrm{IC}$ à $95 \%$ : $1,02-2,82)$.

Conclusion : Étant donné les risques plus élevés de contracter la COVID-19 et d'en décéder dans certains groupes de patients, des programmes d'éducation sanitaire ciblant ces groupes sont recommandés.

$$
\begin{aligned}
& \text { الخصائص الوبائية والسريرية لمرضى كوفيد-19، جمهورية إيران الإسلامية } \\
& \text { مرضيه عربان، محمو د كريمي، حميد كوهيستاني، علي منتظري، دانيال ديلاني } \\
& \text { الخلاصة } \\
& \text { الخلفية: يُعَدُّ مرض فيروس كورونا } 2019 \text { (كوفيد-19 ) من أهم طو ارئ الصحة العامة على مستوى العالم. } \\
& \text { الأهداف: هدفت هذه الدراسة إلى استقصاء الخصائص الوبائية والسريرية لمرضى كوفيد-19 في مدينة ساوه، بجمهورية إيران الإسلامية في عام } \\
& \text {. 2020 }
\end{aligned}
$$


الأرجحية = 2. 2.

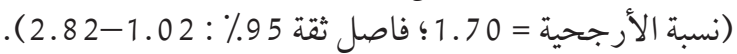

الاستنتاجات: نظرًا لتزايد خخاطر الإصابة بكوفيد-19 و الوفاة الناجمة عنه في صفوف بعضى فئات المرضى، يُوصَى بوضع برامج للتثقيف الصحي تستهدف تلك الفئات.

\section{References}

1. Li Q, Guan X, Wu P, Wang X, Zhou L, Tong Y, et al. Early transmission dynamics in Wuhan, China of novel coronavirus-infected pneumonia. New Engl J Med. 2020;382(13):1199-207. https://doi.org/10.1056/NEJMoa2001316

2. Zhang J, Zhang Y, Ma Y, Ke Y, Huo S, He L, et al. The associated factors of cesarean section during COVID-19 pandemic: a cross-sectional study in nine cities of China. Environ Health Prev Med. 2020;25(1):60. https://doi.org/10.1186/s12199-020-00899-w

3. Poon LL, Peiris M. Emergence of a novel human coronavirus threatening human health. Nature Med. 2020;26(3):317-9. https:// doi.org/10.1038/s41591-020-0796-5

4. Khan A, Althunayyan S, Alsofayan Y, Alotaibi R, Mubarak A, Arafat M, et al. Risk factors associated with worse outcomes in COVID-19: a retrospective study in Saudi Arabia. East Mediterr Health J. 2020;26(11):1371-80. https://doi: 10.26719/emhj.20.130

5. Araban M, Karimy M, Mesri M, Rohani M, Armoon B, Koohestani HR. The COVID-19 Pandemic: Public Knowledge, Attitudes and Practices in a central of Iran. J Educ Community Health.-2021, 8(1):35-40. https://doi10.52547/jech.8.1.35

6. Bastola A, Sah R, Rodriguez-Morales AJ, Lal BK, Jha R, Ojha HC, et al. The first 2019 novel coronavirus case in Nepal. Lancet Infect Dis. 2020;20(3):279-80. https://doi.org/10.1016/S1473-3099(20)30067-0

7. Chen N, Zhou M, Dong X, Qu J, Gong F, Han Y, et al. Epidemiological and clinical characteristics of 99 cases of 2019 novel coronavirus pneumonia in Wuhan, China: a descriptive study. Lancet. 2020;395(10223):507-13. https://doi: 10.1016/So1406736(20)30211-7

8. Chen S, Yang J, Yang W, Wang C, Bärnighausen T. COVID-19 control in China during mass population movements at New Year. Lancet. 2020;395(10226):764-6. https://doi:10.1016/S0140-6736(20)30421-9

9. Bai Y, Yao L, Wei T, Tian F, Jin D-Y, Chen L, et al. Presumed asymptomatic carrier transmission of COVID-19. JAMA. 2020;323(14):1406-7. https://doi:10.1001/jama.2020.2565

10. Wang Y, Yan J, Shi Y, Li P, Liu C, Ma Q, et al. Lack of association between polymorphisms of MASPzand susceptibility to SARS coronavirus infection. BMC Infect Dis. 2009;9(1):51. https://doi:10.1186/1471-2334-9-51

11. Peeri NC, Shrestha N, Rahman MS, Zaki R, Tan Z, Bibi S, et al. The SARS, MERS and novel coronavirus (COVID-19) epidemics, the newest and biggest global health threats: what lessons have we learned? Int J Epidemiol.2020;49(3):717-26. https://doi:10.1093/ije/ dyaa033

12. Sohrabi C, Alsafi Z, O'Neill N, Khan M, Kerwan A, Al-Jabir A, et al. World Health Organization declares global emergency: a review of the 2019 novel coronavirus (COVID-19). Int J Surg. 2020:76:71-76. https://doi:10.1016/j.ijsu.2020.02.034

13. Pan F, Ye T, Sun P, Gui S, Liang B, Li L, et al. Time course of lung changes on chest CT during recovery from 2019 novel coronavirus (COVID-19) pneumonia. Radiology. 2020;295(3):715-21. https://doi:10.1148/radiol.2020200370

14. Shi H, Han X, Jiang N, Cao Y, Alwalid O, Gu J, et al. Radiological findings from 81 patients with COVID-19 pneumonia in Wuhan, China: a descriptive study. Lancet Infecti Dis. 2020;20(4):425-34. https://doi:10.1016/S1473-3099(20)30086-4

15. Yee J, Unger L, Zadravecz F, Cariello P, Seibert A, Johnson MA, et al. Novel coronavirus 2019 (COVID-19): emergence and implications for emergency care. J Am Coll Emerg Physicians Open. 2020;1(2):63-9. https://doi:10.1002/emp2.12034

16. Mesri M, Rouhani MR, Koohestani HR, Azani H, Ahad A, Karimy M. [Clinical features and outcomes of suspected and confirmed COVID-19 patients in Saveh, Iran, 2020.] J Mazandaran Univ Med Sci. 2021;30(194):51-61 [In Farsi].

17. Rothan HA, Byrareddy SN. The epidemiology and pathogenesis of coronavirus disease (COVID-19) outbreak. J Autoimmun. 2020;109:102433. https://doi: 10.1016/j.jaut.2020.102433.

18. Xu G, Yang Y, Du Y, Peng F, Hu P, Wang R, et al. Clinical Pathway for Early Diagnosis of COVID-19: updates from Experience to Evidence-Based Practice. Clin Rev Allergy Immunol. 2020;59(1):89-100. https://doi:10.1007/s12016-020-08792-8

19. Baud D, Qi X, Nielsen-Saines K, Musso D, Pomar L, Favre G. Real estimates of mortality following COVID-19 infection. Lancet Infect Dis. 2020;20(7):773. https://doi:10.1016/S1473-3099(20)30195-X

20. Wu F, Zhao S, Yu B, Chen Y-M, Wang W, Song Z-G, et al. A new coronavirus associated with human respiratory disease in China. Nature. 2020;579(7798):265-9. https://doi:10.1038/s41586-020-2008-3

21. Tuite AR, Fisman DN. Reporting, epidemic growth, and reproduction numbers for the 2019 novel coronavirus (2019-nCoV) epidemic. Ann Intern Med. 2020;172(8):567-8. https://doi:10.7326/M20-0358

22. Li J-Y, You Z, Wang Q, Zhou Z-J, Qiu Y, Luo R, et al. The epidemic of 2019 novel coronavirus (2019-nCoV) pneumonia and insights for emerging infectious diseases in the future. Microbes Infect. 2020;22(2):80-5. https://doi:10.1016/j.micinf.2020.02.002

23. The Lancet. Palliative care and the COVID-19 pandemic. Lancet. 2020;395(10231):1168. https://doi:10.1016/S0140-6736(20)30822-9 
24. Liu T, Hu J, Kang M, Lin L, Zhong H, Xiao J, et al. Transmission dynamics of 2019 novel coronavirus (2019-nCoV). bioRxiv 2020.01.25.919787. https://doi.org/10.1101/2020.01.25.919787

25. Lai S, Bogoch II, Watts A, Khan K, Li Z, Tatem A. Preliminary risk analysis of 2019 novel coronavirus spread within and beyond China. 2020. Southampton: University of Southampton; 2020 (https://www.ethnos.gr/sites/default/files/images/2020/02/worldpop-coronavirus-spread-risk-analysis-v1-25jan.pdf, accessed 26 December 2021).

26. Huang C, Wang Y, Li X, Ren L, Zhao J, Hu Y, et al. Clinical features of patients infected with 2019 novel coronavirus in Wuhan, China. Lancet. 2020;395(10223):497-506. https://doi:10.1016/So140-6736(20)30183-5

27. Wang D, Hu B, Hu C, Zhu F, Liu X, Zhang J, et al. Clinical characteristics of 138 hospitalized patients with 2019 novel coronavirus-infected pneumonia in Wuhan, China. JAMA. 2020;323(11):1061-9. https://doi:10.1001/jama.2020.1585

28. Meo SA, Al-Khlaiwi T, Usmani AM, Meo AS, Klonoff DC, Hoang TD. Biological and epidemiological trends in the prevalence and mortality due to outbreaks of novel coronavirus COVID-19. J King Saud Univ Sci. 2020;32(4):2495-9. https://doi:10.1016/j. jksus.2020.04.004

29. Zumla A, Hui DS, Azhar EI, Memish ZA, Maeurer M. Reducing mortality from 2019-nCoV: host-directed therapies should be an option. Lancet. 2020;395(10224):e35-e6. https://doi:10.1016/So140-6736(20)30305-6

30. Hellewell J, Abbott S, Gimma A, Bosse NI, Jarvis CI, Russell TW, et al. Feasibility of controlling COVID-19 outbreaks by isolation of cases and contacts. Lancet Glob Health. 2020;8(4):e488-e496. https://doi:10.1016/S2214-109X(20)30074-7 